Mitoma, C., Posner, H. S., Reitz, H. C. \& Udenfriend, S. (1956). Arch. Biochem. Biophys. 61, 431.

Reichstein, T. \& Grüssner, A. (1934). Helv. chim. acta, 17, 311.

Roy, R. N. \& Guha, B. C. (1958). Nature, Lond., 182, 319.

Thiers, R. E. \& Vallee, B. L. (1957). J. biol. Chem. 226, 911.
Touster, O., Hutcheson, R. M. \& Rice, L. (1955). J. biol. Chem. 215, 677.

Warburg, O. \& Christian, W. (1938). Biochem. Z. 296, 294.

Winkelman, J. \& Lehninger, A. L. (1958). J. biol. Chem. 233, 794.

Wolfrom, M. L. \& Anno, K. (1952). J. Amer. chem. Soc. 74, 5583 .

\title{
The Determination of Blood Glutathione
}

\author{
By W. W. KAY AND K. C. MURFITT* \\ Mental Hospitals' Group Laboratory, at West Park Hospital, Epsom, Surrey
}

\section{(Received 2 February 1959)}

The nitroprusside method for estimating glutathione is non-specific and suffers from the defect of an unstable colour, although recent improvements (Thompson \& Watson, 1952; Grunert \& Phillips, 1951) appear to make the method more satisfactory. Binkley, Fufii \& Kimmell (1950) used a method based on the Sullivan \& Hess (1936) reaction to estimate glutathione, $\gamma$-glutamylcysteine, cysteinylglycine and cysteine, but in our hands it failed to give reproducible results. We therefore had to seek another method and investigated the observation by Patterson, Lazarow \& Levey (1949) that alloxan and glutathione interact to form a compound characterized by an absorption band at $305 \mathrm{~m} \mu$. Other sulphydryl compounds, e.g. cysteine, react with alloxan but produce dialuric acid by reduction. This last-named substance has an absorption maximum at $275 \mathrm{~m} \mu$ and does not interfere with measurements at $305 \mathrm{~m} \mu$. Some proteins react with alloxan but these can be removed by precipitation, as in the proposed method.

It appeared possible therefore that the reaction with alloxan could be used to estimate glutathione in blood, thus avoiding the interference of the peptides cysteinylglycine and $\gamma$-glutamylcysteine, which, present in blood, react in other methods as glutathione. A very sensitive method, using this reaction, has been developed which readily detects $15 \mu \mathrm{g}$. of glutathione and can be used to estimate it in as little as $0.2 \mathrm{ml}$. of blood. We have not attempted to extend the method to the estimation of glutathione in tissues. The method was used to investigate the blood-glutathione concentration in some cases of therapeutic deep insulin coma.

\section{METHOD}

Principle. Whole lysed blood is deproteinized with trichloroacetic acid, neutralized with buffered $\mathrm{NaOH}$ and

\footnotetext{
* Now at King Edward's School, Witley, Surrey.
}

alloxan is added to develop the compound with glutathione (GSH), which has a characteristic absorption at $305 \mathrm{~m} \mu$.

Reagents. $10 \%(\mathrm{w} / \mathrm{v})$ Trichloroacetic acid.

$0 \cdot 24$ м-Phosphate buffer, $\mathrm{pH} 7 \cdot 6$, prepared by mixing $0.24 \mathrm{M}-\mathrm{Na}_{2} \mathrm{HPO}_{4}$ with $0.24 \mathrm{M}-\mathrm{KH}_{2} \mathrm{PO}_{4}(88: 12, \mathrm{v} / \mathrm{v})$.

Neutralizing $\mathrm{NaOH}$ : this contains in $1.5 \mathrm{ml}$. of solution both $0.24 \mathrm{M}$-phosphate buffer and enough $\mathrm{N}-\mathrm{NaOH}$ to neutralize $0.5 \mathrm{ml}$. of supernatant from protein precipitation $(219: 21, \mathrm{v} / \mathrm{v})$.

Alloxan reagent: $1 \mathrm{mg}$. of alloxan monohydrate $/ \mathrm{ml}$. in dilute $\mathrm{HCl}$ ( 1 drop of conc. $\mathrm{HCl} / 100 \mathrm{ml}$. of water). Prepared freshly and used within $5 \mathrm{~min}$.

Standard GSH: $10 \mathrm{mg} . / 100 \mathrm{ml}$. of water, freshly prepared.

$0 \cdot 1$ M-Glycine solution.

Procedure. A specimen $(0.2 \mathrm{ml}$.) of whole blood from a finger prick is added to $0.6 \mathrm{ml}$. of water. After it has been allowed to stand for $10 \mathrm{~min}$. to haemolyse, $0.8 \mathrm{ml}$. of trichloroacetic acid is added, the liquids are mixed immediately with a glass rod and centrifuged for $5 \mathrm{~min}$.

For each sample of blood two tubes are prepared: test (tube 1) and control (tube 2); each contains $0.5 \mathrm{ml}$. of glycine solution, and 2.9 and $3.9 \mathrm{ml}$. of phosphate buffer are added to (1) and (2) respectively. To each tube $0.4 \mathrm{ml}$. of supernatant from the deproteinized blood and then $1.2 \mathrm{ml}$. of neutralizing $\mathrm{NaOH}$ are added, with mixing.

An alloxan blank (tube 3: $0.5 \mathrm{ml}$. of glycine solution and 4.5 ml. of phosphate buffer), a phosphate blank (tube 4: $6 \mathrm{ml}$. of phosphate buffer) and a standard tube (tube 5: $0.5 \mathrm{ml}$. of glycine solution, $4.3 \mathrm{ml}$. of phosphate buffer and $0.2 \mathrm{ml}$. of standard glutathione) are also prepared.

Fresh alloxan solution $(1 \mathrm{ml}$.) is added to tubes 1 (test), 3 (alloxan blank) and 5 (standard) and the contents of each tube are mixed. The final volume in each tube is $6 \mathrm{ml}$. This procedure is summarized in Table 1.

Readings. All extinctions are read in $2 \mathrm{~cm}$. silica cells in a spectrophotometer set at $305 \mathrm{~m} \mu$. (A Uvispek spectrophotometer was used with hydrogen-arc lamp and slit width $19=0.38 \mathrm{~mm}$., waveband width $5 \mathrm{~m} \mu$.) The control tube 2 is read against the phosphate blank immediately, as its absorption at $305 \mathrm{~m} \mu$ increases slightly on standing. For completion of the reaction $20 \mathrm{~min}$. is allowed and the test tube 1 and standard tube 5 are then read against the alloxan blank (tube 3). 
Table 1. Preparation of tubes for estimation of glutathione

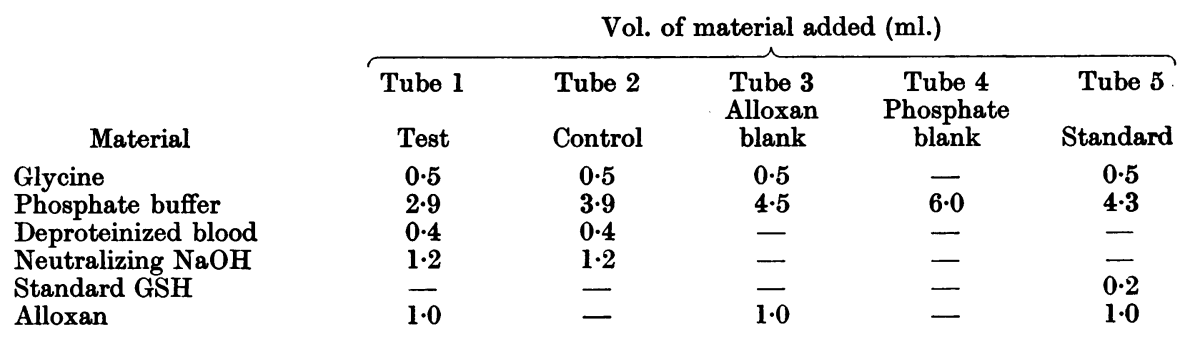

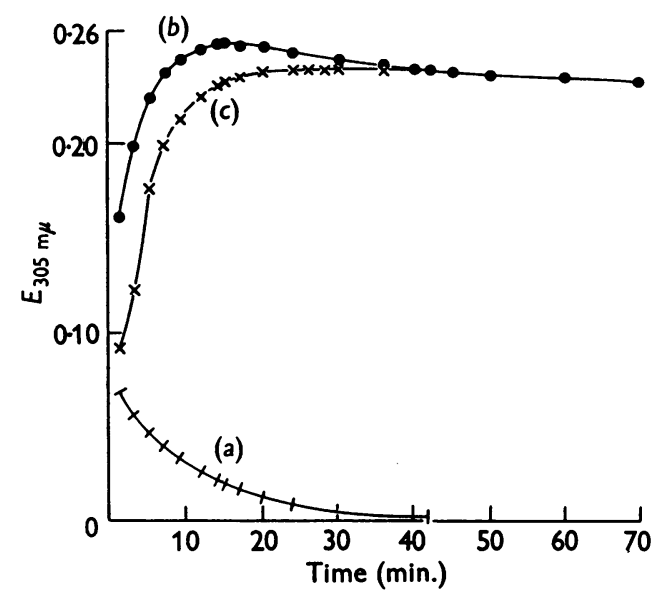

Fig. 1. 'Colour' development curves of reaction between glutathione and $1 \mathrm{mg}$. of alloxan in the presence of $5 \mu \mathrm{g}$. of cysteine and $0.5 \mathrm{ml}$. of $0.1 \mathrm{~m}$-glycine, in a reaction mixture of $6 \mathrm{ml}$. Readings of alloxan blank $(a)$ and glutathione standard $(b)$ were made against phosphate buffer. Standard less blank readings are indicated by (c).

The extinction of the alloxan blank rapidly decreases, whereas that of the standard increases, during the first $20 \mathrm{~min}$. The maximum difference occurs between 20 and 40 min., during which time results are constant (Fig. 1).

Calculation. Let control reading against phosphate blank $=E_{A}$, test reading against alloxan blank $=E_{B}$, standard reading against alloxan blank $=E_{S}$. Then

$40\left(E_{B}-E_{A}\right) / E_{S}=$ mg. of GSH/100 ml. of blood.

\section{RESULTS}

The results of estimating GSH in blood from 14 normal adults (seven male, seven female) are given in Table 2. These values represent only GSH since oxidized glutathione does not react with alloxan (Patterson et al. 1949). The range of values is $24 \cdot 4-37 \cdot 3 \mathrm{mg}$. $/ 100 \mathrm{ml}$. and the mean $30 \cdot 0$, S.D. $\pm 4 \cdot 0$. The mean value for males was $31.6 \mathrm{mg} . / 100 \mathrm{ml}$., s.D. \pm 4.4 , and for females $28.4 \mathrm{mg} . / 100 \mathrm{ml}$, S.D. $\pm 2 \cdot 9$. The difference between these means is not statistically significant $(P<0.2>0 \cdot 1)$. A sex difference does not seem probable, but it would be
Table 2. Concentration of glutathione in normal adult blood

\begin{tabular}{cc} 
Concn. (mg./100 ml.) \\
\hline Males & Females \\
$24 \cdot 4$ & $25 \cdot 4$ \\
$26 \cdot 5$ & $25 \cdot 8$ \\
$31 \cdot 2$ & $26 \cdot 1$ \\
$31 \cdot 6$ & $27 \cdot 6$ \\
$34 \cdot 6$ & $29 \cdot 7$ \\
$35 \cdot 4$ & $30 \cdot 3$ \\
$37 \cdot 3$ & $34 \cdot 0$ \\
Mean $31 \cdot 6$ & $28 \cdot 4$ \\
$\pm 4 \cdot 4$ & $\pm 2 \cdot 9$
\end{tabular}

All 14: mean 30·0, S.D. $\pm 4 \cdot 0$.

unsafe to draw a firm conclusion from such a small series. When corrected by a recovery factor of $86 \%$ (see below), the range of values becomes 28.4 $43.4 \mathrm{mg} . / 100 \mathrm{ml}$. and the mean $34.8 \mathrm{mg} . / 100 \mathrm{ml}$.

Recovery experiments. In a series of recovery experiments in which known amounts of GSH were added to blood after lysis, 78-93\% (mean $86 \%$, s.D. \pm 4 ) of the added GSH was accounted for. The result of one experiment is given in Table 3.

The reasons for the low variable recovery were not explored. It may be due to oxidation of GSH added to blood or to interfering substances in the supernatant after protein precipitation. Until the reasons for the low recovery are settled, the question of the advantage of using added GSH as an internal standard in the method is left open. If the low recovery is due to the oxidation of GSH added to blood, it seems likely that the proportion recovered represents the proportion of the total glutathione in blood present as GSH.

Effect of $\mathrm{pH}$. The effect of various phosphate buffer mixtures is shown in Fig. 2, from which it is evident that the buffer mixture chosen gives maximum formation of the GSH-alloxan compound as measured by extinction.

Since the reaction is sensitive to $\mathrm{pH}$ changes, great care is necessary in the preparation and measurement of the neutralizing solution. Incomplete neutralization in particular gives rise to 
Table 3. Recovery of glutathione added to blood after lysis

All values are given as $\mathrm{mg}$. of glutathione/ $100 \mathrm{ml}$.

$\begin{array}{ccccc}\begin{array}{c}\text { Blood } \\ \text { GSH }\end{array} & \begin{array}{c}\text { GSH } \\ \text { added }\end{array} & \begin{array}{c}\text { Theoretical } \\ \text { value }\end{array} & \begin{array}{c}\text { GSH } \\ \text { found }\end{array} & \begin{array}{c}\text { GSH } \\ \text { recovered }\end{array} \\ \mathbf{2 6 . 9} & \mathbf{1 1 . 6 6} & \mathbf{3 8 . 5 6} & \mathbf{3 7 . 8} & \mathbf{1 0 . 9} \\ \mathbf{2 6 . 9} & \mathbf{2 3 . 3 2} & \mathbf{5 0 \cdot 2 2} & \mathbf{4 6 . 9} & \mathbf{2 0 . 0} \\ \mathbf{2 6 . 9} & \mathbf{3 4 . 9 8} & \mathbf{6 1 \cdot 8 8} & \mathbf{5 6 . 9} & \mathbf{3 0 . 0} \\ & \mathbf{6 9 . 9 6} & & & 60.9\end{array}$

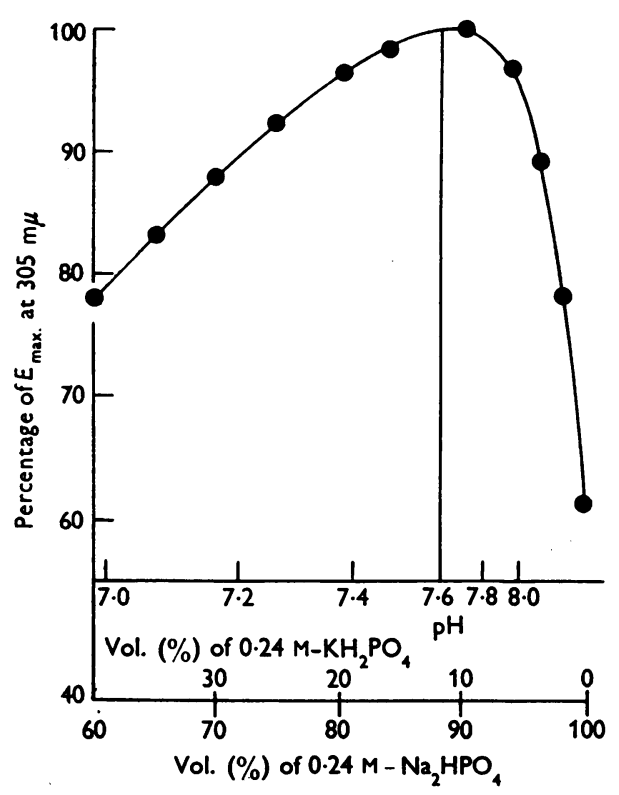

Fig. 2. Effect of various phosphate buffer mixtures on the GSH-alloxan reaction.

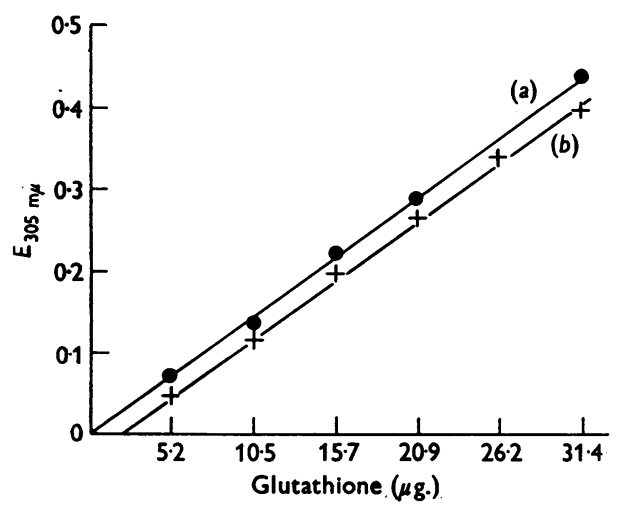

Fig. 3. Calibration curves for glutathione with $1 \mathrm{mg}$. of alloxan, showing the influence of the volume of the solution. (a) Reaction volume of $3 \mathrm{ml}$., to which $3 \mathrm{ml}$. of phosphate buffer was afterwards added; (b) reaction volume of $6 \mathrm{ml}$.

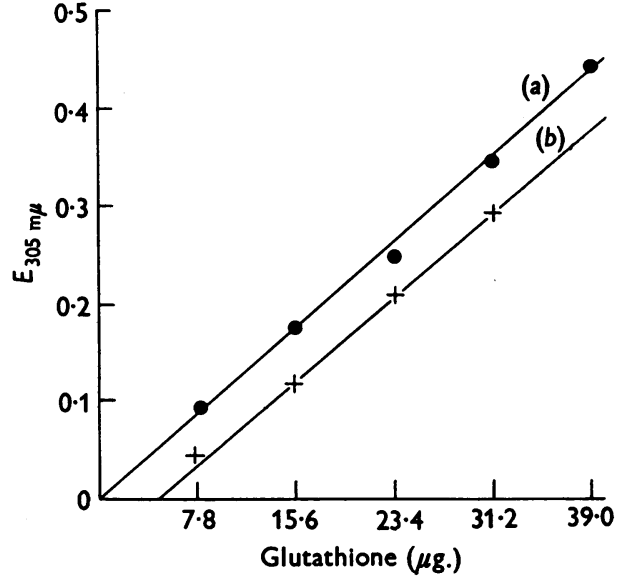

Fig. 4. The presence of $0.2 \mathrm{ml}$. of $0.1 \mathrm{~m}$-glycine (a) improved the reaction between glutathione and $1 \mathrm{mg}$. of alloxan in $6 \mathrm{ml}$. of reaction mixture; (b) reaction without glycine.

errors, e.g. a deficiency of $0.05-0.1 \mathrm{ml}$. of the neutralizing solution may give errors of the order of -3 to $-8 \%$.

Effect of alloxan concentration. Calibration curves obtained from reaction mixtures of $3 \mathrm{ml}$. volume containing $1 \mathrm{mg}$. of alloxan show good proportionality between glutathione and extinction (Fig. 3a), but the same mixtures in $6 \mathrm{ml}$. with $1 \mathrm{mg}$. of alloxan gave a graph which did not intersect the origin (Fig. 3b). As would be expected, $6 \mathrm{ml}$. mixtures containing $2 \mathrm{mg}$. of alloxan produced a straight-line graph passing through the origin.

Effect of glycine. When $0.2 \mathrm{ml}$. of $0.1 \mathrm{M}$-glycine was added, $1 \mathrm{mg}$. of alloxan in a $6 \mathrm{ml}$. mixture gave a good calibration curve (Fig. 4a), comparable to that given when $2 \mathrm{mg}$. of alloxan was used without glycine in $6 \mathrm{ml}$. Fig. $4 b$ was obtained simultaneously without glycine. Thus the addition of glycine has an effect similar to that given by doubling the concentration of alloxan, although it does not give the same extinction values. It has, however, the great advantage of giving a much lower extinction in the blank. 
Activation and inhibition. It was recognized that certain factors in the solutions (possibly heavymetal ions) might be responsible for the anomalous calibration curves obtained in the absence of glycine. A number of compounds known to be 'sequestering agents' for metal ions were therefore included in the reaction mixture. Sodium cyanide and sodium dithionite reacted with alloxan in a way that produced a large extinction even in the

Table 4. Effect of 'sequestering agents' on the reaction between glutathione and alloxan

GSH (20 $\mu \mathrm{g}$.) was treated with $1 \mathrm{mg}$. of alloxan in $6 \mathrm{ml}$. of solution containing the sequestering agent $(0.2 \mathrm{ml}$; $0 \cdot 1 \mathrm{~m})$. Readings were made at $305 \mathrm{~m} \mu$ against the appropriate blank.

$\begin{array}{lc}\text { Sequestering agent } & E \text { due to GSH } \\ \text { Nil } & 0 \cdot 230 \\ \mathrm{Na}_{2} \mathrm{~S}_{2} \mathrm{O}_{3} & 0 \cdot 231 \\ \text { Sodium citrate } & 0 \cdot 237 \\ \text { Sodium tartrate } & 0 \cdot 238 \\ \text { Glycine } & 0 \cdot 280 \\ \mathrm{NaCN} & \text { No reading possible } \\ \mathrm{Na}_{2} \mathrm{~S}_{2} \mathrm{O}_{4} & \text { because of high blank }\end{array}$

Table 5. Effect of various reagents on the reaction between glutathione and alloxan

GSH $(19 \cdot 02 \mu \mathrm{g}$.) was treated with alloxan $(2 \mathrm{mg}$.$) in$ $6 \mathrm{ml}$. of solution containing the test reagent $(0.3 \mathrm{ml}$; $0 \cdot 1 \mathrm{M})$. Readings were made against the appropriate blank at $305 \mathrm{~m} \mu$. The extinction readings of the blanks were all low, except for methionine ( 0.069 against phosphate blank).

\begin{tabular}{|c|c|}
\hline Reagent & $E$ due to GSH \\
\hline Nil & $0 \cdot 285$ \\
\hline Sodium citrate & 0.300 \\
\hline Glycine & $0 \cdot 3 \cdot 20$ \\
\hline$\alpha$-Allanine & 0.322 \\
\hline Threonine & 0.353 \\
\hline Aspartic acid & 0.353 \\
\hline Serine & 0.357 \\
\hline$\beta$-Alanine & $0 \cdot 271$ \\
\hline Methionine & $0 \cdot 135$ \\
\hline
\end{tabular}

Table 6. Inhibition by methionine and cysteine of the glutathione-alloxan reaction

The reaction mixtures $(6 \mathrm{ml}$.) contained alloxan $(2 \mathrm{mg}$.) and, when present, GSH (19.02 $\mu \mathrm{g}$.$) , cysteine (2 \mu \mathrm{g}$.$) and$ methionine ( $2 \mu \mathrm{g}$.).

$\begin{array}{lc}\text { Reaction mixture } & E_{\mathbf{3 0 5} \mathrm{m} \mu} \\ \text { A GSH } & 0 \cdot 293 \\ \text { GSH + cysteine } & 0 \cdot 274 \\ \text { Cysteine } & 0.004 \\ \text { B GSH } & 0 \cdot 289 \\ \text { GSH + methionine } & 0 \cdot 262 \\ \text { Methionine } & 0.009\end{array}$

absence of GSH. Of the other reagents chosen (Table 4), glycine had the greatest effect, but from Table 5 it can be seen that other amino acids had a similar or greater effect. Glycine was selected for the method purely as a matter of convenience. The maximum effect of glycine was given when $0.5 \mathrm{ml}$. of $0.1 \mathrm{M}$-glycine was included in $6 \mathrm{ml}$. of reaction mixture. Glycine also improved the recovery values of added GSH in the method with blood.

$\beta$-Alanine and methionine (Table 5) and cysteine (Table 6 and Fig. 5) have inhibitory effects on the GSH-alloxan reaction. The mechanism of this was not investigated, but there seems to be a distinguishing feature in that, in the presence of glycine, methionine inhibition is not shown, whereas cysteine inhibition is unchanged (Fig. 5). In the absence of glycine, $2 \mu \mathrm{g}$. of either methionine or cysteine showed an appreciable inhibitory effect

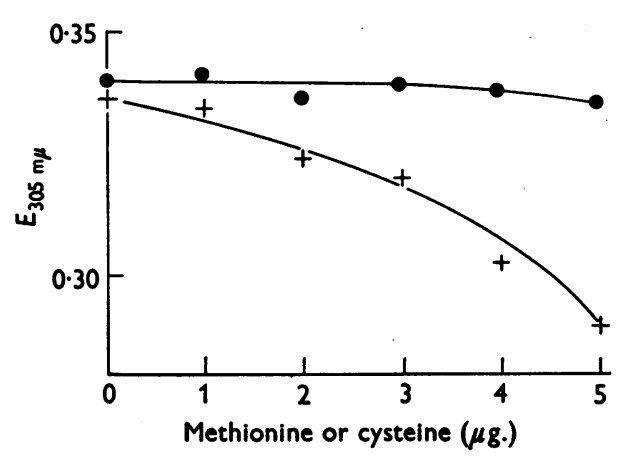

Fig. 5. Comparison of the effect of glycine $(0.5 \mathrm{ml}$.; $0.1 \mathrm{~m})$ on the inhibitive effects of methionine (O) and cysteine $(+)$ on the interaction between $19.02 \mu \mathrm{g}$. of glutathione and $2 \mathrm{mg}$. of alloxan in $6 \mathrm{ml}$. of solution.

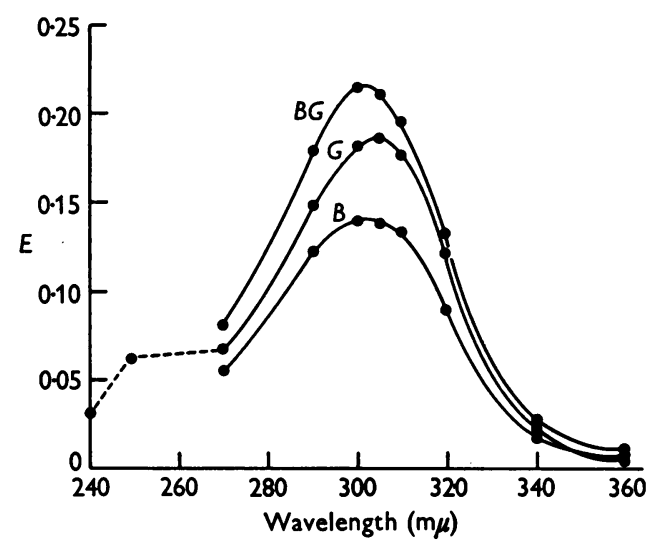

Fig. 6. Ultraviolet-absorption curves of the GSH-alloxan compound $(G)$, the substance in blood reacting with alloxan $(B)$ and of the alloxan compound formed in blood with added GSH $(B G)$. 
(Table 6), which could be important in some other applications of this method.

Specificity. The ultraviolet-absorption spectra of the compounds of alloxan with GSH (curve $G$ ), deproteinized blood (curve $B$ ) and deproteinized blood with added GSH (curve $B G$ ) are given in Fig. 6. The curves, especially $G$, are very similar to those given by Patterson et al. (1949). The molar extinction at $305 \mathrm{~m} \mu$, calculated from curve $G$ on the basis of the substance in lowest concentration (GSH), is 17130 . This value is very close to the maximum value of 17400 found by Patterson et al. In their case, alloxan and not GSH was the substance present in the lowest concentration. It is apparent that under the conditions of their and our experiments quantitatively similar formation of the alloxan-GSH compound occurs.

When blood supernatant was present (curves $B$ and $B G$ ) the extinction due to the alloxan compound could not be measured at wavelengths below $270 \mathrm{~m} \mu$ because of the high absorption by the neutralized supernatant. Although the absorption maxima of the alloxan compound with the reacting substance in blood supernatant (curves $B$ and $B G$ ) occur at about $302 \mathrm{~m} \mu$ and not at $305 \mathrm{~m} \mu$ as with GSH, the curves $B$ and $B G$ are so nearly like that given by GSH $(G)$ that it is reasonable to conclude that the substance from blood that reacts with alloxan is GSH.

The peptides cysteinylglycine and $\gamma$-glutamylcysteine in blood present the problem of possible interference by producing substances which may have absorption bands at or near $305 \mathrm{~m} \mu$. Because these compounds are not readily available, it has not been possible to prove the complete specificity of the method. Cysteinylglycine, however, is produced from GSH by controlled hydrolysis with hot 2 M-phosphoric acid for $1 \mathrm{hr}$. (Binkley et al. 1950). After neutralization it was found that the alloxanreacting material had been destroyed by the hydrolysis.

GSH (35 $\mu$ g.) in $2 \mathrm{~m}$-phosphoric acid, neutralized and allowed to react with alloxan, gave an extinction at $305 \mathrm{~m} \mu$ of 0.393 . GSH (35 $\mu \mathrm{g}$.) hydrolysed with hot $2 \mathrm{M}$-phosphoric acid, neutralized and allowed to react with alloxan, gave an extinction at $305 \mathrm{~m} \mu$ of 0.018 . The fall in extinction, 0.375 , due to hydrolysis of the alloxan-reacting material, corresponds to the extinction of 0.377 given by $35 \mu \mathrm{g}$. of GSH in the alloxan reaction. Thus if cysteinylglycine is formed by hydrolysis of GSH, it does not react with alloxan to give any absorption at $305 \mathrm{~m} \mu$ and does not interfere with the estimation of GSH. Ergothioneine $(29 \mu \mathrm{g}$.) and alloxan did not cause any absorption at $305 \mathrm{~m} \mu$.

Conclusion. The effect of various substances on the interaction between GSH and alloxan indicates that any method for estimating GSH using absorption at $305 \mathrm{~m} \mu$ must exclude interference by substances occurring naturally in blood. The influence of glycine on the reaction appears similar to its effect on the interference by amino acids in the Nakamura \& Binkley method (1948) for cysteine, recorded by Hird \& Springell (1954), in which glycine eliminated the depression of colour production caused by certain other amino acids.

\section{Blood glutathione in therapeutic deep insulin coma}

A short investigation was made of the blood GSH concentration in therapeutic deep insulin coma. By the courtesy of Dr A. S. Thorley, in 1953 four patients were studied. They were adult males who had had eight to 14 comas previously. Blood was collected after onset of coma until recovery. The results are given in Table 7. Blood GSH concentration was not affected in these patients by the state of hypoglycaemic coma or by the amount of insulin given to induce coma. Patient 4 had a slightly subnormal blood GSH both during coma and after recovery when the blood glucose was in the normal range.

In prolonged hypoglycaemic coma, when a patient undergoing therapeutic deep insulin coma fails to recover after being given glucose, abnormal values of blood GSH may occur. In one patient values of $77-90 \mathrm{mg} . / 100 \mathrm{ml}$. were found, the blood glucose being normal or above normal. In another, a value of $65 \mathrm{mg} . / 100 \mathrm{ml}$. was obtained but in two others normal values $(29.8,31.2$ and $33.9 \mathrm{mg}$./ $100 \mathrm{ml}$.) were found. There did not seem to be any simple relationship between the blood GSH and the prolonged coma.

Table 7. Blood concentration of glutathione in therapeutic deep insulin coma

\begin{tabular}{|c|c|c|c|c|c|c|c|}
\hline \multirow{2}{*}{$\begin{array}{c}\text { Patient } \\
\text { no. }\end{array}$} & \multirow{2}{*}{$\begin{array}{l}\text { Units of } \\
\text { insulin } \\
\text { given }\end{array}$} & \multirow{2}{*}{$\begin{array}{l}\text { No. of } \\
\text { coma }\end{array}$} & \multicolumn{4}{|c|}{ Time (min.) after onset of coma } & \multirow{2}{*}{$\begin{array}{l}\text { After } \\
\text { recovery }\end{array}$} \\
\hline & & & \multicolumn{4}{|c|}{ Blood GSH (mg./100 ml.) } & \\
\hline 1 & 320 & 12 & $34 \cdot 8$ & $34 \cdot 4$ & $35 \cdot 7$ & $34 \cdot 4$ & - \\
\hline 2 & 280 & 9 & - & $36 \cdot 2$ & $37 \cdot 1$ & $36 \cdot 8$ & $\overline{34 \cdot 3}$ \\
\hline 3 & 220 & 15 & - & $30 \cdot 6$ & $31 \cdot 5$ & $30 \cdot 0$ & - \\
\hline 4 & 120 & 10 & - & 23.8 & $23 \cdot 4$ & $23 \cdot 1$ & $22 \cdot 3$ \\
\hline
\end{tabular}




\section{SUMMARY}

1. The application of the reaction between glutathione and alloxan, giving a substance characterized by an absorption band at $305 \mathrm{~m} \mu$, to the estimation of glutathione in blood is described.

2. Certain substances influence the reaction: $\beta$-alanine, methionine and cysteine are inhibitors and citrate, glycine and other $\alpha$-amino acids are activators.

3. Some observations of blood glutathione concentration in normal and prolonged therapeutic deep insulin coma are recorded.

\section{REFERENCES}

Binkley, F., Fufii, S. \& Kimmell, J. R. (1950). J.biol. Chem. 186, 159.

Grunert, R. R. \& Phillips, P. H. (1951). Arch. Biochem. Biophys. 30, 217.

Hird, F. J. R. \& Springell, P. H. (1954). Biochem. J. 56, 417.

Nakamura, K. \& Binkley, F. (1948). J. biol. Chem. 173, 407.

Patterson, J. W., Lazarow, A. \& Levey, S. (1949). J. biol. Chem. 177, 197.

Sullivan, M. X. \& Hess, W. C. (1936). J. biol. Chem. 116, 221.

Thompson, R. H. S. \& Watson, D. (1952). J. clin. Path. 5, 25. 